\title{
Increasing the Reliability of Dust Collector Machine IDC001 Using Preventive Maintenance with Continuous Monitoring Activity in Automotive Company
}

\author{
Anastasia Maukar ${ }^{1}$, Pandu Adi Cakranegara ${ }^{2}$ and Tantyo Edo Wicaksana ${ }^{3}$ \\ 1,3)Faculty of Engineering, Industrial Engineering Department, President University \\ 2) Faculty of Business, Accounting Departement, President University \\ Jl. Ki Hajar Dewantara \\ Kota Jababeka,Cikarang, Bekasi - Indonesia 17550 \\ Email: almaukar@president.ac.id, tantyoedo2608@gmail.com
}

\begin{abstract}
As one of the main vital for automotive company, the maintenance of machine is very vital to be maintained and controlled to prevent any meaningless downtime. But during January 2015 until November 2018, machine is the highest downtime contributor for molding line with total downtime 2320.49 hours. Especially for dust collector machine IDC001 that contribute the highest downtime of the machines. It is caused by the current preventive maintenance schedule still not considering the machine reliability. The schedule also cannot represent the actual lifetime of its critical components which are dust tube, shaft, v-belt, and bearing. Moreover, there is no any data recorded about the components performance that make the maintenance team cannot predict the component lifetime accurately. The objectives of this research are to achieve $80 \%$ reliability and to get more data of component performance by proposing the new preventive maintenance schedule and continuous monitoring activity. After several failure functions calculation, then the new preventive maintenance schedule is established. Through the analysis of what the current maintenance system needs today, there are vibration monitoring and dust concentration monitoring activities that will be proposed to get more data to predict the component lifetime in the future. By implementing the proposed preventive maintenance schedule and continuous monitoring activities, the maintenance team able to get more data to predict the component lifetime and the reliability of each component will increase into $80 \%$ with total savings IDR 830,645,805.
\end{abstract}

Keywords: preventive maintenance, continuous monitoring, dust collector machine reliability, failure function

\begin{abstract}
ABSTRAK
Sebagai salah satu faktor vital bagi perusahaan otomotif, perawatan mesin sangat penting untuk dijaga dan dikendalikan agar tidak terjadi downtime yang tidak berarti. Namun selama Januari 2015 hingga November 2018, mesin merupakan kontributor downtime tertinggi untuk moulding line dengan total downtime 2.320.49 jam. Khusus untuk mesin pengumpul debu IDC001 yang menyumbang waktu henti mesin tertinggi. Hal tersebut disebabkan jadwal perawatan preventif yang ada saat ini masih belum memperhatikan kehandalan mesin. Jadwal tersebut juga tidak dapat mewakili umur sebenarnya dari komponen kritisnya yaitu tabung debu, poros, v-belt, dan bantalan. Selain itu, tidak adanya data yang terekam mengenai kinerja komponen membuat tim maintenance tidak dapat memprediksi umur komponen secara akurat. Tujuan dari penelitian ini adalah untuk mencapai keandalan $80 \%$ dan mendapatkan lebih banyak data kinerja komponen dengan mengusulkan jadwal pemeliharaan preventif yang baru dan kegiatan pemantauan berkelanjutan. Setelah beberapa kali penghitungan fungsi gagal, maka jadwal pemeliharaan preventif yang baru dibuat. Melalui analisis kebutuhan sistem pemeliharaan saat ini, terdapat kegiatan monitoring getaran dan monitoring konsentrasi debu yang akan diusulkan untuk mendapatkan lebih banyak data guna memprediksi umur komponen di masa yang akan datang. Dengan menerapkan jadwal pemeliharaan preventif yang diusulkan dan kegiatan pemantauan berkelanjutan, tim pemeliharaan dapat memperoleh lebih banyak data untuk memprediksi umur komponen dan keandalan masing-masing komponen akan meningkat menjadi 80\% dengan total penghematan $\mathrm{Rp}$ 830.645.805.
\end{abstract}

Kata kunci: perawatan preventif, pemantauan berkelanjutan, mesin pengumpul debu, keandalan, fungsi kegagalan

\section{Introduction}

Nowadays, achieving efficiency and effectiveness in the production line are becoming the standard for any manufacturing companies to stay in the tight competition. Especially for PT. X as an automotive company that 
must have a smooth production process in order to reach the fastest production time that will lead to the maximum production capacity. As one of element that become main vital for production line, machines must be maintained and controlled to prevent any disturbance that might be caused downtime. Downtime gives so many disadvantages that caused more costs for the company such as defected parts from that machine, line stop that lead to some delayed process, penalty for late product delivery, and other losses. Thus, in order to minimize the costs from a downtime, it is very important to do machine maintenance since machine is the highest downtime contributor for molding line with total downtime 2320.49 hours during the past 3 years.

Maintenance is a set of activities to make the machine and other components performance become back to its prime condition or original state to minimize the downtime occurred (Dhillon, 2002). One kind of machines in molding line that has the highest downtime during the past 3 years is the dust collector machine with total 11 machines. The function of dust collector is to absorb any dirty air from other machines and produce the fresh air. Currently, these dust collector machines contribute the highest total downtime with total 1,121.70 hours during year 2015 until November 2018. But, in this current situation the most crucial dust collector machine is the dust collector that located on sand preparation line (IDC001), where it filters dust and hot stream that containing a lot of chemical gas such as zinc oxide $(\mathrm{ZnO2})$ from the sand washing process. This machine also as the highest downtime contributor among other dust collector machines with total downtime 179.41 hours. There are four components that give the most downtime for machine IDC001 during the past 3 years the downtime. The total downtime caused by these component failures is 144.38 hours which is these four component failures has $80.48 \%$ contribution. Based on the initial observation, there are some corrective maintenance activities that still used frequently at dust collector machine IDC001. For instance, there was a direct replacement for one of these components in November 2018. Based on this corrective maintenance activity, the company lost IDR 218,528,377 just because the downtime that occurred was 8.40 hours. Based on so many sudden failures from these components, it can be known that the current preventive maintenance schedule still does not represent the current lifetime of the components and have low reliability. The maintenance team only make the schedule based on their experience without any method and historical failure data. But, since there is lack of failure data about these components, the maintenance team cannot predict accurately the component lifetime.

According to Wang, H., et al. (2016), Preventive Maintenance and Corrective Maintenance are the traditional maintenance that will make lower equipment reliability and high maintenance cost. Predictive Maintenance is more efficient and should be implemented first in order to minimize the cost of other maintenances because the Preventive Maintenance runs frequently and regularly that will be spent more cost than predictive maintenance especially for technician costs that must be called regularly. Bengtsson (2004) point out that Predictive Maintenance predicts the lifetime of the machine accurately that used to make the schedule of repairment or replacement to the specific components. Thus, the company should make a new preventive maintenance schedule by considering the failure rate and reliability of the machine. But the predictive maintenance still cannot be implemented since there is lack of data about the component condition. In order to overcome the lack of data to do the Predictive Maintenance, there must be continuous monitoring activity to record the data. In measuring the condition of these components, there will be vibration monitoring and dust concentration monitoring. These monitoring is suitable to be implemented since PT.X has been implemented it in its other plant and also the maintenance team has not any continuous monitoring for this machine that caused so many corrective maintenances occurred

\section{Methods}

Maintenance is about all activities carried out to maintain the condition of an item or equipment, or return it to certain conditions. It is about a conception of all activities needed to maintain the quality of facilities / machines in order to function properly as in the initial conditions (Dhillon, 2002). According to low reliability of the current schedule and lack of data about the component performance, there will be proposed a new preventive maintenance scheduling and continuous monitoring activities. In order to make a new schedule, there will be used reliability concept, failure function, failure distribution, and maintenance interval time.

\subsection{Reliability Concept}

In generating the reliability, its concept is based on the statistical probability theory. Where its purpose is to make sure the tools or machine able to operate properly within certain period of time (Stapelberg, 2009). In the reliability concept, there are 4 elements which are:

1) Probability 
Kurniawan (2013) defines reliability $(R(t))$ as a probability where the system can function properly in a certain period (period t). Since it is a probability, so the value of reliability always between 0 up to 1 . In order to express the reliability mathematically where the continuous variable $(T)$ represent the system time (machine) as long as has failure $(T \geq 0)$, then the reliability itself can be expressed like the equation (1).

$$
R(t)=\operatorname{Pr}(T \geq t)
$$

\section{2) Performance}

As an indicator to know a machine or equipment can operate normally during certain period of time, reliability represent how reliable it is to demonstrate a satisfactory performance if operated.

\section{3) Time}

Time is very important element since reliability always be expressed in certain period of time as a machine operated normally. So, time must be known to express how long the machine can operate normally and when it has to be recovered from its failure. Those can be represented as mean time to failure (MTTF) and mean time to repair (MTTR).

$>$ Mean time to failure (MTTF)

According to Ansori and Mustajib (2013), mean time to failure (MTTF) is the average time interval (time interval) of every component failure occurrence. The data used is the time interval data for failure, then the difference is calculated between the time of the failure occurrence. The calculation of mean time to failure can be expressed manually by using equation (2).

$$
M T T F=\int_{0}^{\infty} t f(t) d t
$$

$>$ Mean time to repair (MTTR)

Mean time to repair (MTTR) is the average distance of time used to do repairment or replacement. The MTTR value is obtained from the same calculation as the MTTF calculation. The data used are historical data of the length time to do replacement and repairment of components. The calculation of mean time to repair can be expressed as same as MTTF by using equation (3).

\section{4) Condition}

$$
M T T R=\int_{0}^{\infty} t h(t) d t
$$

A condition from a machine performance can be known by looking at its reliability. It means every value of reliability is different since the condition of a machine also different in certain period of time.

\subsection{Failure Function}

Failure function is the statistical approach to predict when a machine has failure. It is very useful in order to increase the reliability of a machine, since the reliability itself always be questioned because of unexpected failure occurrences. Thus, in order to generate new preventive maintenance schedule, there are some calculation of function to predict the failure interval which are probability density function (PDF), cumulative distribution function (CDF), and reliability function.

\subsubsection{Probability Density Function}

Probability density function shows the form and characteristics of a failure distribution. It is to determine the probability of a failure from machine or components in certain of time as the continuous variable $(t)$ and has a continuous distribution $f(t)$ in every $f(t)$ axis point (Rusavel, 2015). The curve of probability density function can be seen in the Figure 1. 




Figure 1. Probability Density Function Graph

The area under the curve line is the total probability of failure during certain period $(t)$ with total value equal to 1. For example, the probability of failure between tx and ty can be seen on the equation (4).

$$
\int_{t x}^{t y} f(t) d t=1, \text { where } f(t) \geq 0
$$

\subsubsection{Cumulative Distribution Function}

Cumulative distribution function is used to determine probability of failure before time $(t)$. It is can be seen as the graph in the Figure 2.

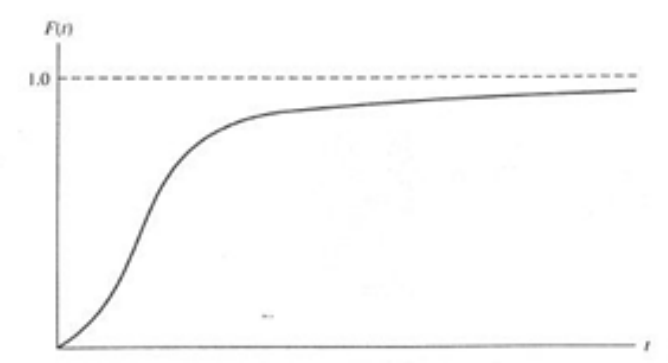

Figure 2. Cumulative Distribution Function Graph

In order to calculate the cumulative distribution function, the calculation can be seen on the equation (2-5).

Where:

$$
F(t)=1-R(t)=\operatorname{Pr}(T<t)
$$

And

$$
F(0)=0
$$

$$
\lim _{t \rightarrow \infty} F(t)=1
$$

As it is the cumulative of failure probability, the cumulative distribution function has value between $0 \leq F(t) \leq$ 1 , and if there is value of $t$ tends to infinity $(\infty)$ then $F(t)$ is equal to 1 .

\subsubsection{Reliability Function}

Reliability function is the function to determine the probability when a machine can operate well in certain level of condition based on its time function. Normally it is used when the reliability already known in different condition level (Lewis, 1987). The reliability function is denoted as $\mathrm{R}(\mathrm{t})$ and it can be calculated by following the equation (8).

$$
R(t)=\int_{0}^{\infty} f(t) d t=1-F(t)
$$

From the equation (8), it can be known that the reliability function is the opposite of failure function and has value between 0 up to 1 . The reliability function graph can be seen in the Figure 2.4. 


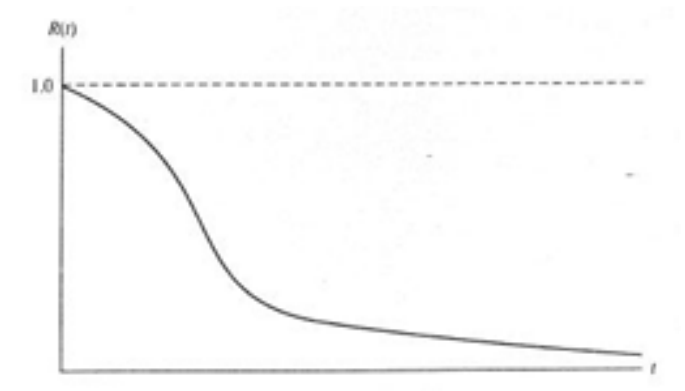

Figure 3. Reliability Function Graph

\subsection{Failure Distribution}

In order to determine the value of reliability from a machine, there will be used continuous random variables which is the time itself $(t)$. As it uses continuous random variable, the distribution must be determined because each distribution has different failure function to express each calculation. In this research, there are weibull distribution, lognormal distribution, exponential distribution, and normal distribution.

\subsection{Maintenance Interval Time}

In proposing a new preventive maintenance schedule, maintenance interval time is an important element that must be calculated to achieve the reliability as the research objective. Maintenance interval time is the time between each maintenance or the time during a machine performs well before get handled by the maintenance team. In the proposed maintenance schedule, the maintenance interval time obtained by calculation the failure functions that already explained before which are probability density function, cumulative distribution function, reliability function, and cumulative hazard function or failure rate. In achieving new maintenance interval time, maintenance cost must be considered too where the shorter it is the higher its cost. The total cost can be obtained through the calculation of preventive cost, corrective cost, and the cumulative hazard function that can be seen on equation (9).

$$
C(t) \quad=\frac{C p+[C f \times H(t)]}{t}
$$

Where:

$\mathrm{C}(\mathrm{t}) \quad=$ Cost per unit of time

$\mathrm{Cp} \quad=$ Total cost of preventive maintenance

$\mathrm{Cf} \quad=$ Total cost of corrective maintenance

$\mathrm{H}(\mathrm{t}) \quad=$ Cumulative hazard function

$\mathrm{t} \quad=$ Maintenance interval time

\section{Result and Discussion}

This research is based on the failure data from January 2015 until November 2018. Based on the machine downtime breakdown, it can be known that dust collector machine IDC001 is the highest downtime contributor

Total Stoppage Losses (h) of Dust Collector

Machines (January 2015 - November 2018)

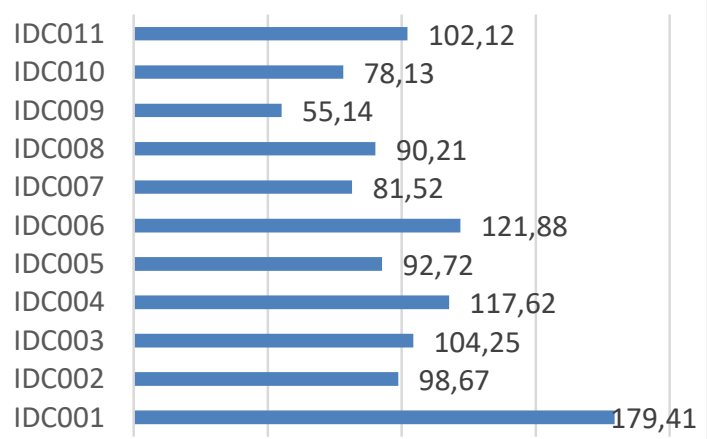

Pareto Chart of Failure Frequency by IDC 001 Components (January 2015 - November 2018)

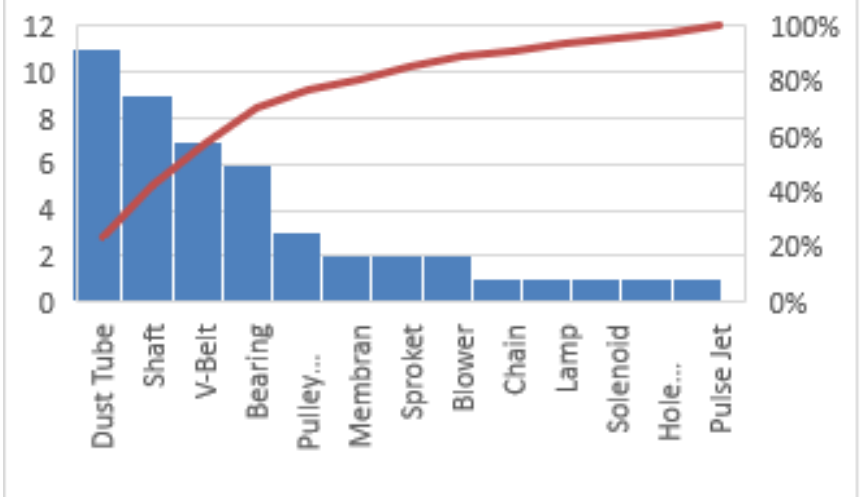


in Casting Area as the critical machine. The critical components known from the pareto chart based on the failure frequency.

Figure 4. Identification of Critical Machine and Critical Components (January 2015 - November 2018)

After the critical components already known, then the failure data that should be collected is already confirmed. In order to create the preventive maintenance scheduling, the data calculation begins by calculating the time to repair (TTR) and time to failure (TTF) for each critical component. Then, the result of time to repair (TTR) and time to failure (TTF) calculation will be tested by using index of fit and goodness of fit distribution in order to know the distribution that fit with data of each critical component. As the result from the distribution test is the type of distribution for each data, then the mean time to failure (MTTF), mean time to repair (MTTR), and also the replacement interval for each critical component can be calculated based on the chosen distribution. The replacement interval for each critical component will be calculated to achieve $80 \%$ reliability. Then, the schedule can be made.

\subsection{Summary of MTTF and MTTR Result}

Before the calculation of MTTF and MTTR, the best fitted distribution for each data must be found through the Index of Fit test and Goodness of Fit test. Index of Fit ( $r$ ) is the value of coefficient correlation to know how strong the relationship between parameter in a distribution function, where the relationship is linear and its value between -1 until +1 . If the value of Index of Fit is near -1 or +1 , then it can be said there are strong relationship and high correlation between the parameters. But, if the value of Index of Fit is close to zero, then it can be said the opposite.

Goodness of Fit is a hypothesis testing to determine whether an expected parameter distribution is equal to the parameter distribution obtained that will be used to calculate maintenance interval and MTTF. This test will make clear the distribution that must be chosen by accepting the null hypothesis $(\mathrm{H} 0)$, where the result of $\mathrm{p}$-value is larger than the significant level of this research with value 0.05 . Below are two hypotheses in goodness of fit test:

$\mathrm{H}_{0}=$ The assumed distribution fits for the data

$\mathrm{H}_{1}=$ The assumed distribution does not fit for the data

The chosen distribution as the best fitted distribution not only just has $p$-value larger than 0.05 and accept the null hypothesis $(\mathrm{HO})$, but also has the highest $\mathrm{p}$-value result among the others. There also Anderson Darling $(A D)$ value to consider the chosen distribution, where it must have the smallest $A D$ value. After all of the critical components have each best fitted distribution, then the mean time to failure (MTTF) can be calculated based on the parameter of each chosen distribution. Not only the MTTF, but also the reliability and the maintenance interval also can be calculated soon. The same way also applied to calculate the MTTR for each component. Here the result of MTTF and MTTR calculation with its best fitted distribution.

Table 1. MTTF and Parameter of Chosen Distribution

\begin{tabular}{|l|c|c|c|c|c|c|}
\hline \multirow{2}{*}{ Component } & \multirow{2}{*}{ Distribution } & \multicolumn{3}{|c|}{ Parameter } & $\begin{array}{c}\text { Standard } \\
\text { Deviation }\end{array}$ & \multirow{2}{*}{ MTTF (h) } \\
\cline { 3 - 6 } & & Scale & T-Med & Shape & \\
\hline Dust Tube & Lognormal & 0.580 & 1161.970 & & & 1375.020 \\
\hline Shaft & Normal & & 1462.090 & & 712.047 & 1462.090 \\
\hline V-Belt & Weibull & 2430.360 & & 7.248 & & 2277.550 \\
\hline Bearing & Lognormal & 0.440 & 2057.360 & & & 2266.570 \\
\hline
\end{tabular}

Table 2. MTTR and Parameter of Chosen Distribution

\begin{tabular}{|l|c|c|c|c|c|c|}
\hline \multirow{2}{*}{ Component } & \multirow{2}{*}{ Distribution } & \multicolumn{3}{|c|}{ Parameter } & $\begin{array}{c}\text { Standard } \\
\text { Deviation }\end{array}$ & MTTR (h) \\
\cline { 3 - 6 } & & Scale & T-Med & Shape & \\
\hline Dust Tube & Lognormal & 0.040 & 7.825 & & & 7.832 \\
\hline Shaft & Weibull & 2.523 & & 14.814 & & 2.436 \\
\hline V-Belt & Lognormal & 0.082 & 0.650 & & & 0.652 \\
\hline Bearing & Weibull & 5.433 & & 21.434 & & 5.298 \\
\hline
\end{tabular}




\subsection{Summary of Component Replacement Interval Result}

In order to make the preventive maintenance scheduling, the proposed schedule must need the replacement interval to be determined. Where this replacement interval means the interval time when the component should be replaced with the new one as it is already scheduled. In the corrective maintenance, this interval named mean time to failure (MTTF) but since this is scheduled, so it would be named as the replacement interval. It is calculated based on the parameters of the distribution that fit with the failure data, since each distribution has different formula and parameter to calculate it. In order to make the schedule with the preferred reliability, the right replacement time must be found by using trial and error. Where the shorter it is, the higher its reliability. The calculation of replacement interval time will always be related with the failure function calculation such as probability density function, cumulative distribution function, and cumulative hazard function. The new replacement interval is calculated based on the failure function calculation to achieve $80 \%$ reliability.

Table 3. New Component Replacement Interval to Achieve $80 \%$ Reliability

\begin{tabular}{|l|c|c|c|c|}
\hline \multicolumn{1}{|c|}{ Component } & MTTF (h) & Reliability & $\begin{array}{c}\text { New Replacement } \\
\text { Interval (h) }\end{array}$ & Reliability \\
\hline Dust Tube & 1375.02 & $38.53 \%$ & 720 & \multirow{2}{*}{$80 \%$} \\
\hline Shaft & 1462.09 & $49.95 \%$ & 870 & \\
\hline V-Belt & 2277.55 & $53.50 \%$ & 1970 & \\
\hline Bearing & 2266.57 & $43.36 \%$ & 1270 & \\
\hline
\end{tabular}

\subsection{Proposed Maintenance System}

After the new replacement interval already calculated, then the proposed maintenance system can be made. The proposed maintenance system consists of preventive maintenance schedule and continuous monitoring activities including the analysis of the current maintenance system. The preventive maintenance schedule will be shown in the end of the research together with the continuous monitoring schedule. In the current maintenance system, there are corrective and preventive maintenance. Where the preventive maintenance consists of lubrication, inspection, and replacement activities. Based on the analysis through direct observation, there are so many uncertainty factors that can make the component failure before the scheduled preventive maintenance. The most of great deals that the maintenance team faced toward the dust collector IDC001 failure is there is no actual visualization of the machine condition that can be monitored by the team. The team made the preventive maintenance schedule only based on the component information from the supplier and also the analysis that made by the team through the meeting, no based on any preventive method.

As the maintenance team still has no direct visualization of the current condition of the machine, so in this proposed maintenance system there will be dust concentration monitoring and also vibration monitoring to conduct continuous monitoring to the current condition of the critical components which are dust tube, shaft, $\mathrm{v}$-belt, and bearing. Where the maintenance team in PT. X already trained to do hearing inspection and always use it to know the shaft and bearing failure. In other side, they know the dust tube failure visually to the thick air that come out from the machine which means its dust concentration is high and beyond the standard.

\section{* Vibration Monitoring}

The first proposed continuous monitoring activity is vibration monitoring. This is because the damage to the shaft and bearing begins with a change in vibration on the machine. Therefore, continuous monitoring of vibrations caused by the machine must be done. The maintenance activities in continuous monitoring are measuring vibrations on an ongoing basis. The purpose of this continuous monitoring is to find out the vibrational changes that occur in the machine. Based on the vibration monitoring schedule, the vibration monitoring for shaft and bearing components is every 4 weeks or 20 working days. As the purpose of this monitoring is to know the current condition of the components, so the schedule not only based on every 4 weeks, but also will be held 1 day before the scheduled replacement day. This consideration is to prevent a replacement to a component that still performed well. The analysis of vibration monitoring will be shown in a graph that shows the vibration level. 


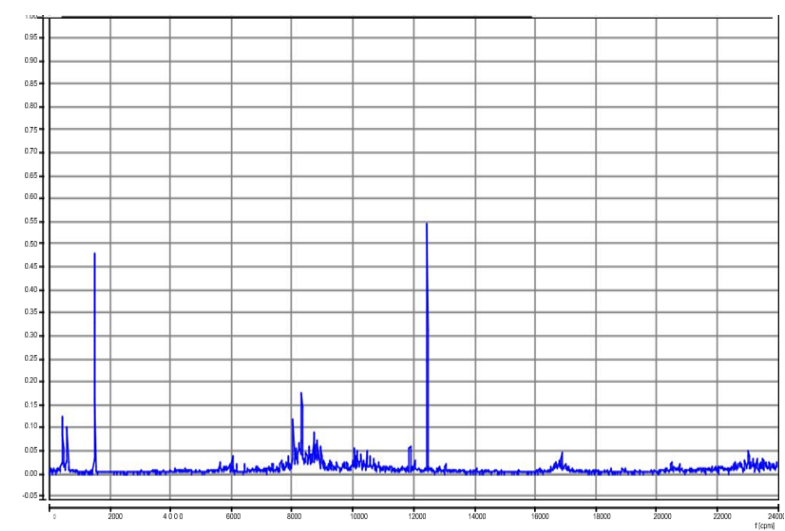

Figure 5. Example Vibration Result by MP 2 Software

\section{* Dust Concentration Monitoring}

In this second continuous monitoring activity, there will be monitoring activity to the dust concentration in the fresh air that come out as the output of dust collector machine. This activity must be implemented since a high dust concentration air will make the production floor become stopped directly as the air environment will be started polluted. When this situation happened, there will be known that there is a hole to the dust tube component. Thus, the purpose of this continuous monitoring activity is to find out the dust concentration changes through the sensor that should be installed on the way of fresh air come out from dust collector machine. Actually, this monitoring has been implemented recently in one of dust collector machines in other plant of PT. X which is dust collector 'IDC004'. But, since the dust collector machine IDC001 as the critical machine is still have not installed a sensor for the dust concentration monitoring, then this monitoring activity should be proposed too. In every decision that has been made, there will be also evaluation after the replacement or inspection that has been conducted. The evaluation is about the real condition compared to their analysis through the monitored dust concentration. This comparison will make the decision in the future become more accurate than before. The analysis of dust concentration monitoring will be shown in a graph that shows the dust concentration level towards the company's standard.

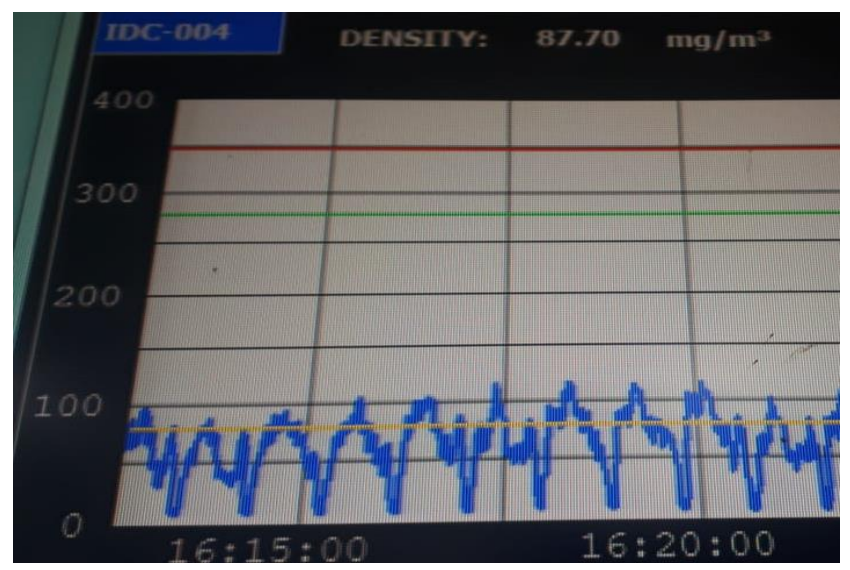

Figure 6. Example Dust Concentration Monitoring Result Through Sensor

Therefore, based on the new component replacement interval and the continuous monitoring activities then the proposed maintenance schedule can be seen in Figure 7. 

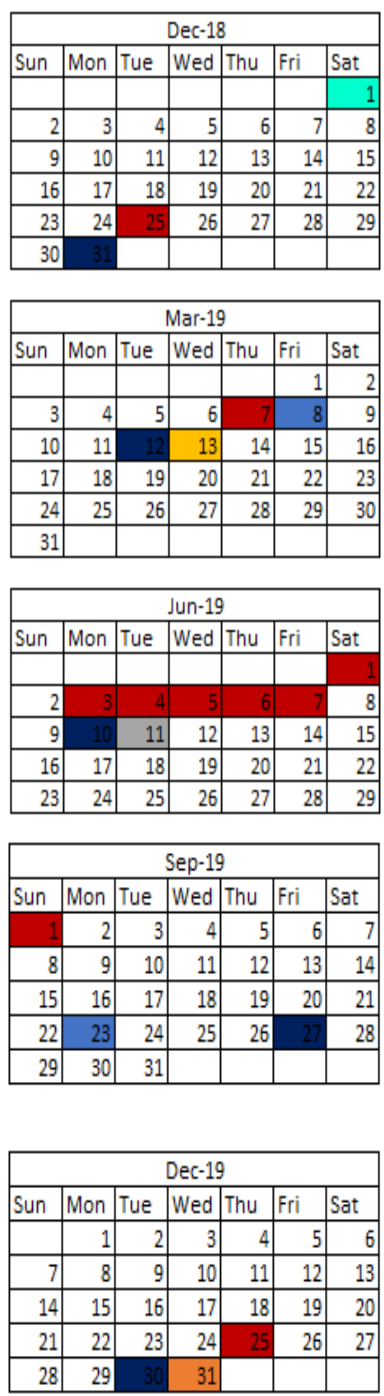
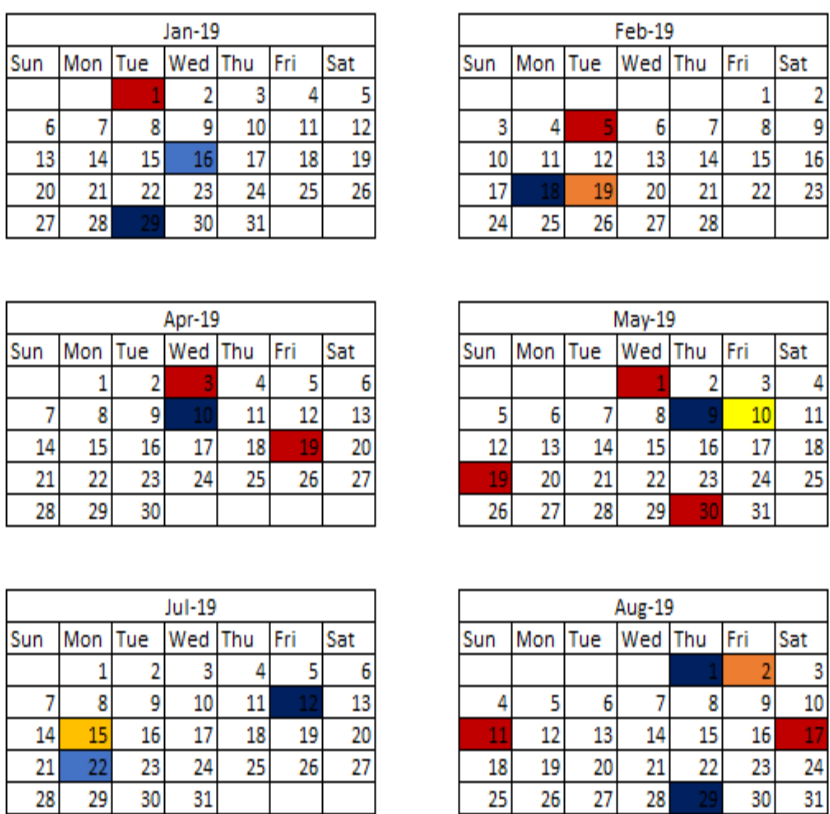

\begin{tabular}{|r|r|r|r|r|r|r|}
\hline \multicolumn{7}{|c|}{ Oct-19 } \\
\hline Sun & Mon & Tue & Wed & Thu & Fri & Sat \\
\hline & & & 1 & 2 & 3 & 4 \\
\hline 5 & 6 & 7 & 8 & 9 & 10 & 11 \\
\hline 12 & 13 & 14 & 15 & 16 & 17 & 18 \\
\hline 19 & 20 & 21 & 22 & 23 & 24 & 25 \\
\hline 26 & 27 & 28 & 29 & 30 & 31 & \\
\hline
\end{tabular}

\begin{tabular}{|r|r|r|r|r|r|r|}
\hline \multicolumn{7}{|c|}{ Nov-19 } \\
\hline Sun & Mon & Tue & Wed & Thu & Fri & Sat \\
\hline & & & & & & 1 \\
\hline 2 & 3 & 4 & 5 & 6 & 7 & 8 \\
\hline 9 & 10 & 11 & 12 & 13 & 14 & 15 \\
\hline 16 & 17 & 18 & 19 & 20 & 21 & 22 \\
\hline 23 & 24 & 25 & 26 & 27 & 28 & 29 \\
\hline 30 & & & & & & \\
\hline
\end{tabular}

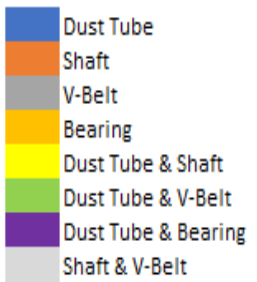

Shaft \& Bearing

V-Belt \& Bearing

Dust Tube \& Shaft \& V-Belt

Dust Tube \& Shaft \& Bearing

Shaft \& V-Belt\& Bearing

All Components

National Holiday

Vibration Monitoring

\section{Conclusion}

Figure 7. Proposed Maintenance Schedule (Dec'18 - Dec'19)

Based on the calculation and analysis to the all of collected data, there comes several conclusions to answer the research objectives. There are four components that dominantly caused high downtime to the machine which are dust tube, shaft, $v$-belt, and bearing. During this past 3 years, these components contribute $86.15,21.88,4.57,31.78$ hours for total downtime of the machine. The current MTTF of dust tube, shaft, v-belt, and bearing are 1375.02, 1462.09, 2277.55, 2266.57 hours respectively while the current MTTR of these components are 7.83, 2.44, 0.65, and 5.30 hours.

Based on the result of MTTF, the current reliability of each component can be known which are $38.53 \%, 49.95 \%, 53.50 \%$, and $43.36 \%$ respectively. Based on the current reliability, it can be known that each component still has low reliability that caused high possibility to have failure. In the proposed preventive maintenance schedule, the new replacement interval of dust tube, shaft, vbelt, and bearing will be every $720,870,1970$, and 1270 hours respectively to achieve $80 \%$ reliability. In order to maintain the reliability, there will be predictive maintenance activity which are vibration and dust concentration monitoring. The proposed maintenance system will save IDR $830,645,805$ during December 2018 until December 2019.

\section{References}

1. Ansori, N., and Mustajib, M. I., (2013).Sistem Perawatan Terpadu, Graha Ilmu, Yogyakarta,.

2. Bengtsson, M.,(2004) Condition Based Maintenance System - An Investigation of Technical Constituents and Organizational Aspects, Mälardalen University Press, Sweden. 
3. Blanchard, B. S., (2010). System Engineering and Analysis, Prentice Hall International, USA.

4. Dhillon, B. S.,(2002) Engineering Maintenance: A Modern Approach, CRC Press LLC, USA.

5. Ebeling, C. E., (1997). An Introduction to Reliability and Maintainability Engineering, The MCGraw Hill Companies, Singapore.

6. Girdhar, P., and Scheffer, C.,(2004). Practical Machinery Vibration Analysis and Predictive Maintenance, Elsevier, BurlingtoN.

7. Kange, B., and Lundell, S., Evaluation of the Potential for Predictive Maintenance, Chalmers University of Technology, Sweden, 2015.

8. Kurniawan, F., (2013). Manajemen Perawatan Industri : Teknik dan Aplikasi Implementasi Total Productive Maintenance (TPM), Preventive Maintenance dan Readibility Centered Maintenance (RCM), Graha Ilmu, Yogyakarta,

9. Lewis, E. E., (1987). Introduction to Reliability Engineering, John Wiley and Sons, Canada.

10. Mobley, R. K., (2002). An Introduction to Predictive Maintenance, Butterworth-Heinemann, United States of America.

11. Rusavel, A.N., (2015). Perencanaan Aktivitas Pemeliharaan Peralatan Bongkar Muat Peti Kemas PT. Pelabuhan Indonesia II Cabang Teluk Bayur, Final Assignment, Industrial Engineering Department, Andalas University, West Sumatra.

12. Stapelberg, R.F., (2009). Handbook of Reliability, Availability, Maintainability and Safety in Engineering Design, 1st ed, Springer-Verlag London,

13. Swanson, L., (2001). Linking Maintenance Strategies to Performance, International Journal of Production Economics, Vol 70(3), pp.237-244.

14. Wang, H., Ye, X., and Yin, M., (2016). Study on Predictive Maintenance Strategy, International Journal of u- and e-Service, Science and Technology, Vol.9 (4), pp.295-300. 